\title{
The Multi-level Homologous Logic and Prospective Research Concept on the Effects of Creativity and Ambidextrous Leadership on Innovative Performance
}

\author{
Katarzyna Piórkowska \\ Dept. of Strategy and Management Methods, Wroclaw University of Economics \\ 53-345, Wroclaw, Poland \\ E-mail: katarzyna.piorkowska@ue.wroc.pl
}

Received: Feb. 28, 2017

Accepted: March 31, $2017 \quad$ Published: April 1, 2017

doi:10.5296/jmr.v9i2.10846

URL: https://doi.org/10.5296/jmr.v9i2.10846

\begin{abstract}
The aim of the paper is to develop a conceptual research framework with regard to the relationships between creativity, ambidextrous leadership and innovative performance incorporating a multi-level homologous perspective. The aim has been achieved through critical extensive literature studies. The overarching key finding is that the effects of creativity and ambidextrous leadership on innovative performance may be examined within a multi-level homologous approach illustrating the associations among creativity, creative performance, and organizational performance at the individual, team, and organizational performance. The first section presents a general overview of the creativity phenomenon, namely creativity conceptualization as well as antecedents and effects at individual, team, and organizational level. The creativity with regard to ambidextrous leadership has been highlighted in the second section. Then, creativity, ambidextrous leadership and innovative performance in terms of a multi-level homologous research concept (specifically, a model, propositions, and measurement tools proposed) have been illustrated in the third section. Final remarks and research directions have been posed in the last section.
\end{abstract}

Keywords: creativity, ambidextrous leadership, creative and innovative performance 


\section{Introduction}

The creativity phenomenon emerged strongly from works of Chassel (1916) (as mentioned in Kalis, Roke \& Krumina 2014), Wallas (1926), Guilford (1950) \& Torrance (1962, 1974). Creativity has been agreed to be a contributor towards inter alia performance, creative performance, innovative performance, competitiveness, longevity, entrepreneurship, survival, long-term value (e.g. Amabile, 1997; Anderson, Potočnik \& Zhou, 2014; Fischer, Oget \& Cavallucci, 2016; George, 2007; Horng, Tsai \& Chung, 2016; Mumford \& Gustafon, 1988; Oldham \& Cummings, 1996; Runco, 2004; Woodman, Sawyer \& Griffin, 1993) at the individual, team, organizational, cultural, and even societal level (a systems view) (e.g. Anderson, Potočnik \& Zhou, 2014; George, 2007; Hennessey \& Amabile, 2010; Shalley, Zhou \& Oldham, 2004). The creativity phenomenon might be considered as either an outcome (novel and useful on the basis of originality, fluency, and flexibility) or a process (cognitive and behavioural). As Wang \& Ahmed (2004) state, an organisation's ability to innovate is recognised as one of the determinant factors for organisations to survive and succeed. Specifically, creativity and innovation indeed constitute crucial elements not only for competitive advantage (e.g. DeFillippi, Grabher \& Jones, 2007; Florida, 2002), yet also just for organizational survival since they enable organizations to adapt to environmental changes - it has been evidenced for instance in the hotel industry (e.g. Wong \& Pang, 2003).

Moreover, creativity is encompassed in ambidextrous leadership in terms of exploitation and exploration behaviour (e.g. Zacher, Robinson \& Rosing, 2016). While much research has been conducted in the realm of creativity, innovation as well as leadership, there is no evidence in terms of the associations between ambidextrous leadership, creativity, and innovative performance at different levels of analysis. Hence, the aim of the paper ${ }^{\mathrm{i}}$ is to contribute to that gap and to develop a conceptual research framework with regard to the relationships between creativity, ambidextrous leadership and innovative performance incorporating a multi-level homologous perspective. The aim has been achieved through critical extensive literature studies.

The remainder of this study is organized as follows. The first section presents a general overview of the creativity phenomenon, namely creativity conceptualization as well as antecedents and effects at individual, team, and organizational level. The creativity with regard to ambidextrous leadership has been highlighted in the second section. Then, creativity, ambidextrous leadership and innovative performance in terms of a multi-level homologous research concept (specifically, a model, propositions, and measurement tools proposed) have been illustrated in the third section. Final remarks and research directions have been posed in the last section.

\section{Creativity phenomenon: general overviews}

\subsection{Conceptualization of creativity}

Intensive research has been conducted in psychology (e.g. Amabile, 1996; Hennessey \& Amabile, 2010) and management (e.g. George, 2007; Shalley, Zhou \& Oldham, 2004) to better explain and understand creativity phenomenon as well as it has been explored from 
various perspectives, e.g. cognitive, neurological, personal, or organizational as well as in terms of different theoretical approaches such as confluence approach (Sternberg \& Lubart, 1999), systems theory (Csikszentmihalyi, 1988), contextual methodology (Mayer, 1999), social psychology (Amabile, 1996), Social Cognitive Theory \& socio-constructivist approaches (Edwards-Schachter et al., 2015), psychological trait theory (Hennessey and Amabile, 2010), behavioural theories \& functionalist approaches (e.g. Bird, 2002). The representative conceptualizations have been presented in Table 1.

Table 1. Creativity - selected representative definitions

\begin{tabular}{|c|c|}
\hline Author & Definition \\
\hline $\begin{array}{l}\text { Amabile (1997); Andersen, Potocnik, \& } \\
\text { Zhou (2014); Dewett (2004); Oldham \& } \\
\text { Cummings (1996); West \& Farr (1990); } \\
\text { Zhou \& George (2001) }\end{array}$ & $\begin{array}{l}\text { Production/generation of novel and useful ideas by } \\
\text { an individual or small group of individuals working } \\
\text { together. }\end{array}$ \\
\hline $\begin{array}{l}\text { Sternberg and Ben-Zeev (2001); } \\
\text { Sternberg, Kaufman \& Pretz (2002) }\end{array}$ & $\begin{array}{l}\text { The ability to produce outcomes that are novel, high } \\
\text { quality and appropriate to the task. }\end{array}$ \\
\hline $\begin{array}{l}\text { Cropley and Cropley (2010); Woodman, } \\
\text { Sawyer, \& Griffin (1993) }\end{array}$ & $\begin{array}{l}\text { The idea generation component of the innovation } \\
\text { process; starting point for innovation; generation of } \\
\text { effective novelty. }\end{array}$ \\
\hline $\begin{array}{l}\text { Hui (2015); Kaufman (2015); Tan \& } \\
\text { Wong (2015) }\end{array}$ & Life phenomenon - both personal and socio-cultural. \\
\hline Rungo \& Jaeger (2012) & $\begin{array}{l}\text { Criteria for assessing creative performance: } \\
\text { originality and effectiveness. }\end{array}$ \\
\hline Simonton (2008); Soroa et al. (2015) & $\begin{array}{l}\text { Interaction between the abilities (process) and } \\
\text { external pressures (context) of a person that } \\
\text { generates a result (product) that is useful, new and } \\
\text { noticeable for a specific context. }\end{array}$ \\
\hline Plucker \& Beghetto (2004) & $\begin{array}{l}\text { The interplay between ability and process by which } \\
\text { an individual or group produces an outcome or } \\
\text { product that is both novel and useful within some } \\
\text { social context. }\end{array}$ \\
\hline $\begin{array}{l}\text { Baas, De Dreu \& Nijstad (2011); } \\
\text { Bledow, Rosing \& Frese (2013); Soroa } \\
\text { et al. (2015) }\end{array}$ & $\begin{array}{l}\text { Dynamic perspective - the interaction between } \\
\text { thinking styles, affective dispositions, and } \\
\text { motivational preferences. }\end{array}$ \\
\hline Kalis, Roke \& Krumina (2014) & $\begin{array}{l}\text { A complex view: cognitive and personal } \\
\text { components of creative individuals and their mutual } \\
\text { interaction with their environment during the } \\
\text { process of creative acting are included. }\end{array}$ \\
\hline Haner (2005) & $\begin{array}{l}\text { Both creativity and innovation processes need to be } \\
\text { seen as complex, partly iterative and partly } \\
\text { simultaneous efforts. }\end{array}$ \\
\hline Urban \& Jellen (2010) & $\begin{array}{l}\text { A model of creativity including six interactive } \\
\text { components that function together for and in the }\end{array}$ \\
\hline
\end{tabular}




\begin{tabular}{|c|c|}
\hline & $\begin{array}{l}\text { creative process: divergent thinking, general } \\
\text { knowledge and thinking base, specific knowledge } \\
\text { base and area specific skills, focusing and task } \\
\text { commitment, motivation, and openness and } \\
\text { tolerance of ambiguity. }\end{array}$ \\
\hline Csikszentmihalyi (2006) & $\begin{array}{l}\text { Interactions of a system made up of three elements: } \\
\text { a culture featuring symbolic rules, a person who } \\
\text { introduces something new into this symbolic } \\
\text { domain and experts who acknowledge and validate } \\
\text { the innovation. }\end{array}$ \\
\hline Fischer, Oget \& Cavallucci (2016) & $\begin{array}{l}\text { Creative individuals interpret the standards of their } \\
\text { environment to establish original mental } \\
\text { connections and to re-interpret them giving a unique } \\
\text { meaning. Creativity requires imagination and } \\
\text { transgression of working standards of a given } \\
\text { organizational environment. }\end{array}$ \\
\hline Glaveanu (2015) & $\begin{array}{l}\text { The creative process is a form of action by which } \\
\text { actors, materially and symbolically, alone and in } \\
\text { collaboration with others, move between different } \\
\text { (audience) positions and, in this process, } \\
\text { imaginatively construct new perspectives on their } \\
\text { course of action and its resulting artifacts which } \\
\text { afford greater reflexivity and the emergence of } \\
\text { novelty. It engages self-other, symbolic-material, } \\
\text { and past-present-future relations that turn it into a } \\
\text { social, embodied, and temporal act. }\end{array}$ \\
\hline Edwards-Schachter et al. (2015) & $\begin{array}{l}\text { A transferable competence comprising individual } \\
\text { characteristics (creative personality, personal traits, } \\
\text { thinking styles), creative processes and the acts to } \\
\text { develop creative products taking into account the } \\
\text { context where creativity occurs (social context, } \\
\text { collective learning environments). }\end{array}$ \\
\hline
\end{tabular}

In line with all those aforementioned definitions concerning creativity, it is regarded to reflect temporal dynamics, social context, engagement in the context from double perspective (self and other) and moving between these orientations. Indeed, the creativity construct constitutes a multidimensional and disentangling construct. It has been authorized, for instance, by the representatives of propulsion theory (Sternberg, 1999; Sternberg, 2006; Sternberg \& Kaufman, 2012; Sternberg, Kaufman \& Pretz, 2001, 2002) that creativity can be of different kinds, depending on how it propels existing ideas forward ranging from minor replications to major redirections in thinking what is reflected in propulsion theory involving extension strategies (replication, redefinition, forward incrementation, advanced forward incrementation) and replacement ones (redirection, reconstruction, reinitiation, synthesis) (Mecca \& Mumford, 
2014).

The creativity construct involves multiple ontological, epistemological, and methodological associations (e.g. Batey, 2012; Bouchard \& Bos, 2006; Fischer, Oget \& Cavallucci, 2015). Ontologically, it might cover at least individual traits, processes, and outcomes. Individual traits reflect the ability to generate and extend ideas, concepts, and methods in novel ways (Csikszentmihalyi, 1988). The creative process is conceptualized cognitively and behaviourally as an iterative sequence of thoughts and a form of action (a socio-cultural act) by which individuals move between different positions constructing new perspectives with reflexivity and emergence of novelty that is useful (Glaveanu, 2015; Horng, Tsai \& Chung, 2016; Lubart, 2001; Shalley, Zhou \& Oldham, 2004) and constitutes an outcome of a creative process. Those elements of creativity occur at multiple levels of analysis (at least individual, team and organizational) (Anderson, Potočnik \& Zhou, 2014) since epistemologically, the creativity concerns individuals, teams, organizations as well as even society. It is convergent with invariants set out by Fischer, Oget \& Cavallucci (2015) that reflect various levels of creativity constructs: the originality of imagination and the concept of transgression, the interdependence of participants, and dependence on cultural, social, and disciplinary contexts. Consequently, Hennessey \& Amabile (2010) call for a systems view of creativity that involves a variety of interrelated interdisciplinary conditions that ought to be recognized at multiple levels. Hence, creativity ought not to be analysed only at the individual level, yet it should involve collaboration relationships among members of a team (e.g. particular teams, top management teams) and organization (Kind \& Kind, 2007).

\subsection{Multi-level creativity antecedents}

Specifically, individual, team and organizational level of creativity with its particular antecedents is proposed to be considered.

Individual level. With regard to antecedents and determinants of individual creativity, the following ones attracted much scholars' attention: cognition, cognitive style and thinking styles, emotion and imagination, motivation, goal orientation (especially learning goal orientation), intelligence and personality traits (e.g. creative personality, proactive personality), and environment (context) including both organizational conditions and external environment. Obviously, individual differences and various contextual factors can interact to affect creativity.

Cognitive individual differences reveal in divergent and convergent creativity (Eysenck, 2003; Runco, 2007; Shalley, Zhou \& Oldham, 2004; Soroa et al., 2015; Tan \& Wong, 2015) that involves a dynamic perspective of creativity comprehended as an interaction between thinking styles, affective dispositions, and motivational preferences (Bledow, Rosing, \& Frese, 2013). Divergent thinking requires the ability to make unique combination of issues and transform ideas to unusual concepts (Park, Chun and Lee. 2016). It has been evidenced that divergent thinking is a good predictor of creative potential (e.g. Torrance, 1962; Woodman, Sawyer \& Griffin, 1993). Complimentary, convergent thinking that involves logical search and information processing paradoxically constitutes a critical determinant of individual creativity as well (e.g. Cropley \& Cropley, 2012; Runco, 2004). It is salient to 
enable divergent ideas to become useful (Runco \& Acar, 2012). Tan \& Wong $(2015,239)$, analysing those aspects deeper, highlight the importance of 'convergence in divergence for emergence' emphasising the iterative cycle of creativity. The cognitive style conception is based on Kirton's (1976, 1994) Adaptation-Innovation Theory. This theory posits that individuals have natural and preferred means of creative problem solving according to a bipolar continuum of cognitive styles: adaptors and innovators. Adaptors tend to operate within given paradigms and procedures while innovators tend to develop problem solutions that are qualitatively different from previous ones. Consequently, bipolar cognition dimensions have been recognized: rule-oriented cognitive strategies and set-breaking cognitive strategies (Soroa et al., 2015). When it comes to thinking styles as individuals' predominant patterns of using mental abilities to manage tasks (Zhang \& Sternberg, 2009), nonlinear dynamical thinking style (called also a creative thinking style) is regarded as crucial since it is predisposed to novelty and individuals manage to adopt new perspectives (Groves \& Vance, 2014).

Regarding emotion, two dominant dimensions have been recognized as critically salient: positive affect (mood) facilitating cognitive flexibility and negative one calling for perseverance (De Dreu, Baas \& Nijstad, 2008; Russell \& Carroll, 1999; Soroa et al., 2015). Moreover, positive mood causes that cognitive or motivational processes are enhanced and their creative thinking and problem solving skills are facilitated (Shalley, Zhou \& Oldham, 2004). In some cases - context dependent - negative mood also might inflence creativity (Zhou \& George, 2001). It has been evidenced that feelings and emotions can consciously and unconsciously influence cognition (Groves \& Vance, 2014). That is the reason why emotional aspect is a constituent in the linear/nonlinear thinking construct. Moreover, goal orientation has been proposed as a moderator of the effects of mood on creativity (De Dreu, Baas \& Nijstad, 2008; Roskes, De Dreu \& Nijstad, 2012). Similarly, imagination on one hand constitutes a facilitator of linear thinking (reproductive imagination) and on the other hand, it is focused on mental processes within an inner world (creative imagination) (e.g. Liang, Chang \& Hsu, 2014). Additionally, imaginative thinking supports flexibility in forming innovative solutions (Groves \& Vance, 2014; Ogilvie, 1998).

With regard to motivation as the factor influencing creativity, intrinsic, task-focused motivation is essential to creativity (Sternberg, 2006) and is determined by internal locus of control (Dewett, 2004). Moreover, motivation divided into proactive and preventive has been evidenced as relevant in enhancing creativity (Higgins, 1997, 2014).

Regarding goal orientation that is defined as an individual approach to achievement settings based on their goal preferences (Elliott \& Dweck, 1988), two types of them are taken into considerations when it comes to creativity issues: performance and learning goal orientation. Vandewalle (2001) distinguished individuals with learning goal orientation as those that elicited adaptive behaviour during problem-solving tasks and preferred a task that develops their abilities by gaining new skills and engage in challenging goals (Vandewalle et al., 1999). In contrary, people with performance goal orientation do not exert effort to change or improve their abilities (Vandewalle, 2001). Vandewalle, Cron \& Slocum (2001) evidenced that an individual with learning goal orientation is more likely to exert effort, reveal 
self-efficacy, and a difficult goal level. Hirst, Van Knippenberg \& Zhou (2009) found that learning orientation had a positive main effect on creativity what was also replicated by Gong, Huang \& Farh (2009). Learning goal orientation encompasses learning styles and for instance Nesta's studies (2014) evidenced that the most favoured by professionals working in creative industries is Pragmatist - individuals seek to apply theoretical concepts in their job.

In accordance with personality, it is said that creativity is embodied in a particular type of personality: the individual creative genius (Batey, Furnham \& Safiullina, 2010; Bilton \& Leary, 2002; DeFillippi, Grabher \& Jones, 2007; Furnham \& Bachtiar, 2008) associated with intelligence (Batey, Chamorro-Premuzic \& Furnham, 2009; Batey, Furnham \& Safiullina. 2010; Furnham \& Bachtiar, 2008) Sternberg \& Lubart (1991, 1995) have supported the salience of inter alia the following personality attributes for creative functioning: willingness to overcome obstacles, willingness to take sensible risks, willingness to tolerate ambiguity, and self-efficacy - all of them concern so called creative personality (Zhou, 2003). It has been evidenced that proactive personality is positively associated with individual creativity (Kim, Hon \& Crant, 2009). Proactive personality refers to individuals who initiate changes regarding amongst others their job performance and organizational environment, are engaged in active role orientation, and willingly take risk (Bateman \& Crant, 1993; Seibert, Crant \& Kraimer, 1999; Seibert, Kraimer \& Crant, 2001). George \& Zhou (2001) examined the influence of two of the Five Factors traits: openness to experience and consciousness on creative behaviour and they hypothesized, amongst others, that openness to experience results in high levels of creative behaviour if feedback valence is positive as well as that conscientiousness results in low levels of creative behaviour if supervisors are engaged in close monitoring. In general, openness to experience and extraversion - regarding as two of the Five Traits positively correlated with creativity, especially with divergence (Runco, 2014; Werner et al., 2014).

Although most studies on creativity are concentrated on the attributes of creativity, the context illustrating an interaction between individuals and context (environmental conditions) ought to be also taken into account (Runco, 2004; Sternberg, 2006). For instance, according to the investment theory (Sternberg, 2006; Sternberg \& Lubart, 1991, 1995), creativity requires a confluence of six distinct but interrelated resources: intellectual abilities (synthetic, analytic, and practical-contextual skills), knowledge, thinking styles (a legislative style), personality, motivation, and environment. This environment - organizational context involves mainly job characteristics e.g. job creativity requirements, supervisor close monitoring, developmental feedback (Amabile et al., 1996; Oldham \& Cummings, 1996; Shalley, Gilson \& Blum, 2000; Zhou, 2003), group interaction, incentive structures, failure-tolerant cultures (Amabile, 1996; Bilton \& Leary, 2002; Woodman, Sawyer \& Griffin, 1993) and leadership (Shin \& Zhou, 2003) as well as supporting creativity it advocates the creative-process engagement resulting in positive creative attitudes and satisfaction (e.g. Shalley, Gilson \& Blue, 2000; Gilson \& Shalley, 2004). The organizational context supporting creativity might be enhanced or hindered by external environmental settings and conditions as well. It has been evidenced that dynamic and uncertain environment, especially involving high-level technology enterprises, furthers developing creativity in organizations 
(e.g. Inkinen \& Kaivo-oja, 2009).

Team level. Regarding team level creativity, it ought to be stressed that teams represent social context in which individual creativity is enacted (Fan et al., 2016). The following antecedents of team level creativity have been recognized by scholars: characteristics of a team (e.g. composition, structure, tenure, tenure diversity), the integration process, coordination, flow information (Fischer, Oget \& Cavallucci, 2015; cf. Bouchard \& Bos, 2006), task interdependence (Gilson \& Shalley, 2004), job complexity, routinization (Anderson, Potočnik \& Zhou, 2014), and leadership (especially transformational) (Bono \& Judge, 2003; Gong et al., 2009; Shin \& Zhou, 2003). The routinization aspects seem to be critical in evaluating creativity. Team members and the teams' as the whole propensity to be creative and abilities to set creative and innovative performance also seem to be dependent upon the degree of tasks routinization. Those who use routinized tasks make adjustments to their performances in response to prior outcomes (Feldman, 2000). The leadership role, especially in the realm of transformational leadership and managerial innovation-oriented performance, might support individuals' creative behaviour. Leader innovation-oriented performance in contrary to execution-oriented performance, invokes the manager's ability to devise and implement novel initiatives within the firm. Behaviourally innovative leaders demonstrate the willingness to change, to foster new ideas as well as commitment to encourage new ways of doing things. Not only is individual goal orientation salient as it refers to how individuals define and strive for success, yet learning goal orientation at the team level is also significant and may contribute to enhance creativity and innovative performance. People with high learning goal orientation consistently strive toward mastery of a skill or task in an effort to increase competence, whereas those with high performance goal orientation focus more immediately on demonstrating their competence through meeting performance goals (Taing et al., 2013). The goal orientation implies the goal difficulty issue. The scholars indicated that on one hand team goals are connected to the performance and, on the other hand, that goal difficulty level interacts with goal commitment to predict performance (Klein et al., 2001). Moreover, it seems that the primary factors influencing team level creativity are embedded and are reflected with transactive memory systems (TMSs) that might explain how team members use mutual reliance as well as share knowledge and learn so as to complete collective tasks and contribute to both individual and team performance (Fan et al., 2016; Lewis \& Herndon, 2011). It has been evidenced that TMSs positively influence team performance and team effectiveness (Lewis \& Herndon, 2011; Ren \& Argote, 2011); therefore it is worth examining the associations between TMSs and team creative and innovative performance. Moreover, it is suggested taking into considerations the creative self-efficacy construct (understood as the belief to possess the abilities to produce creative outcomes) since it has been stated that creative self-efficacy partially mediates the relationship between TMSs and the individual's innovative behaviour (Fan et al., 2016). Team-level creativity involves also a strategic level, i.e. top management teams as key decision makers in some organizations what is supported by the upper echelons paradigm (Dewet, 2004).

Organizational level. When it comes to the antecedents of organizational level creativity, the characteristics of an organization are very salient (Fischer, Oget \& Cavallucci, 2015; cf. 
Bouchard \& Bos, 2006; Woodman, Sawyer \& Griffin, 1993), especially organizational culture, resources, rewards, strategy, structure, and focus on technology (Anderson, Potočnik \& Zhou, 2014; Woodman, Sawyer \& Griffin, 1993). Shalley, Zhou \& Oldham (2004) have examined the following characteristics influencing creativity: job complexity, relationship with supervisors, relationships with co-workers, rewards and evaluation, time deadlines and goals, and spatial configurations of work settings. Moreover, the role of developing organizational climate for creativity and supportive for innovation at the organizational level is significantly stressed (Amabile, 1996; Jung, Wu \& Chow, 2008; Patterson et al., 2005). Amabile et al. (1996) and Amabile's (1997) componential theory of creativity highlights that social environment components have impact on individual and team creativity. Specifically, a conceptual model underlying assessment of perceptions of the work environment for creativity developed by Amabile et al. (1996) refers to such characteristics like encouragement of creativity, managerial practices regarding autonomy vs. freedom, resources, pressures, and organizational impediments to creativity. George (2007) grouped contextual influences into four main categories: signals of safety, creativity prompts, supervisors and leaders, and social networks. Admittedly, social network configurations in the organization might precipitate to enhance creativity (e.g. Perry-Smith, 2006), especially in terms of the actors who are close to structural holes (Burt, 2004).

\subsection{Creativity effects: creative and innovative performance}

Creativity and innovation constructs seem to disclose the organizational ambidexterity phenomenon reflecting the synchronous pursuit of both creativity and innovation: exploration (creativity) vs. exploitation (innovation) (Gupta, Smith \& Shalley, 2006). Creativity constitutes the starting point (impetus) for innovation (Massaro, Bardy \& Pitts, 2012; Woodman, Sawyer \& Griffin, 1993; Zacher, Robinson \& Rosing, 2016). Innovation constitutes the development and intentional implementation of creative (new and useful) ideas by individuals, teams, and organizations (Cropley, Kaufman \& Cropley, 2011; Turkson \& Appiah, 2009; West \& Farr, 1990). Roberts (1988) divided innovation into two stages: invention (the generation of novel ideas) and exploitation (implementation of these ideas in the sense of value innovation). In a similar vein, scholars make explicit distinction and identify the first stage of innovation with creativity (Bledow et al., 2009; Cropley, Kaufman \& Cropley, 2011; West, 2002), however, it might be also envisaged that both creativity and innovation processes overlap and constitute partly iterative and partly simultaneous cycles (Haner, 2005) leading to outcomes of innovation - innovative performance (subjective and objective). Anderson, Potočnik \& Zhou $(2014,1298)$ proposed the following integrative definition of creativity and innovation: 'Creativity and innovation at work are the process, outcomes, and products of attempts to develop and introduce new and improved ways of doing things. The creativity stage of this process refers to idea generation, and innovation refers to the subsequent stage of implementing ideas toward better procedures, practices, or products. Creativity and innovation can occur at the level of the individual, work team, organization, or at more than one of these levels combined but will invariably result in identifiable benefits at one or more of these levels of analysis.' Hence, the interchange between the creativity actor (e.g. an individual, a team, an organization) and engagement in a 
creative process leads to a creative outcome so called creative performance that finally results in innovative performance. A creative outcome is supposed to be novel, fluent and flexible.

Taking into account three levels of creativity, i.e. individual and collective (team and organizational) level, creative performance might be explained regarding those levels of analysis. Specifically, creative performance at the individual level is the outcome of a complex interchange between an individual and the context. It is convergent with the componential theory that highlights creativity as the phenomenon concentrated on an individual and contextual factors determining creative performance (e.g. Amabile, 1996; Gilson \& Shalley, 2004). Creative performance at the team level is a result of e.g. the interaction among team members, their shared mental models, routinization degree, learning orientation degree, etc. Creative performance at the organizational level is an output of creativity at the individual and team level, yet not simply aggregated one.

Innovative performance at the individual and team level concerns the idea implementation intended to produce better outcomes, i.e. ideas, procedures, processes, practises, products, services (Anderson, Potočnik, \& Zhou, 2014; Woodman, Sawyer \& Griffin, 1993). Innovative performance at the organizational level is the final innovative (valuable, novel, and useful) product or service leading to organizational effectiveness and competitive advantage (e.g. Cropley, Kaufman \& Cropley, 2011; Davis, 2009).

\section{Creativity and ambidextrous leadership}

Creativity is strictly associated with leadership. There is always a position exterior to the creative actor (Glaveanu, 2015) as well as the creator endeavours to bring others to a particular issue in the 'multidimensional creative space' (Sternberg, 2006, 96). Leaders, especially in creative industries, ought to be able to respond to changing market conditions and forces (Armstrong \& Page, 2015). Leadership has been recognized as one of the predictors of creativity and innovation (e.g. Williams \& Foti, 2011; Zacher \& Johnson, 2014; Zacher, Robinson \& Rosing, 2016; Zhou \& Hoever, 2014). Creative leadership needs the abilities to balance contradictory issues, i.e. commercial constraints and creative freedom, fear of failure and appetite for risk, competition and collaboration, automation and craft skills, long term strategy and short-term conditions (Armstrong \& Page, 2015, 15). Those constraints and the arguments that leadership for innovation necessitates different roles are entailed with the ambidextrous character of leadership for innovation reflecting that organizations need to and are able to involve two types of behaviour to facilitate creativity and innovation: exploration (experimentation and search) and exploitation (implementation and execution) (Dyduch, Bratnicki, 2010; March, 1991; Van de Van et al., 1999). Indeed, it has been evidenced that ambidextrous organizations have greater potential to innovate (Gibson \& Birkinshaw, 2004; Taylor \& Helfat, 2009).

The ambidexterity leadership theory for innovation proposes that leaders reflect opening and closing behaviour positively predicting exploration (experimenting, making challenging assumptions) and exploitation behaviour (adhering to standards, avoiding risks, focusing on goal achievement) respectively (Gupta, Smith \& Shalley, 2016; Zacher, Robinson \& Rosing, 2016). Opening leadership behaviour has been defined as behaviour that encourages to do 
things differently, to experiment, to think independently. In contrary, closing leadership behaviour is understood as leader behaviour that reduce variance in follower behaviour by taking corrective actions, setting specific guidelines, and monitoring goal achievement (Rosing, Frese \& Bausch, 2011). The ambidexterity leadership theory for innovation enacts that innovative performance is the highest when both exploration and exploitation behaviour are high (Rosing, Frese \& Bausch, 2011). Ambidextrous leadership theory posits that the interaction of this complementary leadership behaviour is expected to be more effective regarding enhancing individual and team innovation than a single leadership style (Zacher \& Rosing, 2015). Moreover, ambidexterity is an important antecedent of innovation at the individual, team, and organizational level and all levels participants have to manage the tension between exploration and exploitation to be innovative (Bledow et al., 2009; Gibson \& Birkinshaw, 2004; Zacher, Robinson \& Rosing, 2016).

\section{Creativity, ambidextrous leadership and innovative performance - a multi-level homologous research concept}

\subsection{A conceptual research model and propositions}

As creativity research results involve multiple epistemological, theoretical, and methodological issues what in many cases make comparison very difficult (Fischer, Oget \& Cavallucci, 2016), it is suggested investigating creativity construct simultaneously at multiple levels of analysis. It can be done incorporating homologous multi-level modelling (Klein \& Kozlowski, 2000).

Leadership with its ambidextrous rationale is encompassed in every level and facet of creativity and innovative performance might be evaluated both subjectively and objectively. The proposed conceptual research framework is presented in Figure 1.

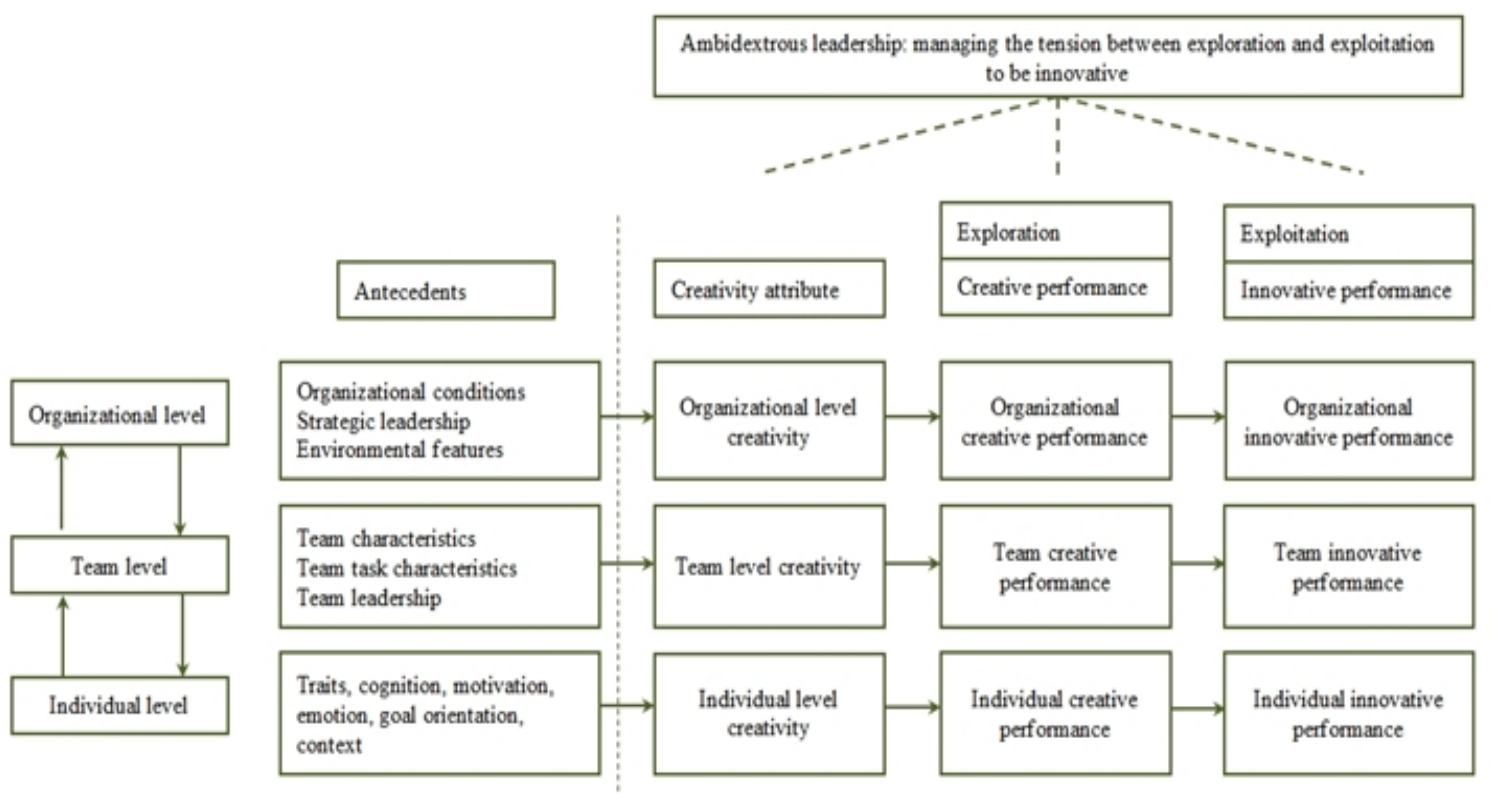

Figure 1. A conceptual research framework 
As well as this, the following primary propositions have been formulated:

Proposition 1: Traits, cognition, motivation, emotion, goal orientation, context constitute the antecedents of individual level creativity.

Proposition 2: Individual level creativity is positively associated with individual creative performance.

Proposition 3: Individual exploration behaviour supports individual creative performance.

Proposition 4: Individual creative performance is positively associated with individual innovative performance.

Proposition 5: Individual exploitation behaviour supports individual innovative performance.

Proposition 6: Team characteristics, team task characteristics, and team leadership constitute the antecedents of team level creativity.

Proposition 7: Individual level creativity is positively associated with individual creative performance.

Proposition 8: Team members exploration behaviour supports team creative performance.

Proposition 9: Team creative performance is positively associated with team innovative performance.

Proposition 10: Team members exploitation behaviour supports team innovative performance.

Proposition 11: Organizational conditions, strategic leadership, and environmental features constitute the antecedents of organizational level creativity.

Proposition 12: Organizational level creativity is positively associated with organizational creative performance.

Proposition 13: Strategic leader exploration behaviour supports organizational creative performance.

Proposition 14: Organizational creative performance is positively associated with organizational innovative performance.

Proposition 15: Strategic leader exploitation behaviour supports organizational innovative performance.

Proposition 16: Ambidextrous leadership permeates creativity at every epistemological level (individual, team, and organizational).

Proposition 17: There are continuous emergent bottom up and top down effects between an individual and a team level as well as between a team and an organizational level.

\subsection{Research design: Measurement tools}

The current base of methods and techniques used in the research on creativity entailed the 
consequences for the measurement tools proposed in the paper as follows:

Creative thinking abilities and creative potential

TCT-DP developed by Urban (2004) and Urban \& Jellen (2010) - an alternative method to the Torrance Tests of Creative Thinking elaborated by Torrance (2007), which have several weaknesses including insufficient validity and complicated measuring procedures (Kalis, Roke \& Krumina, 2014). The respondents are asked to complete the uncompleted drawing regarding 14 criteria.

\section{Linear/Nonlinear Thinking Style Profile (LNTSP)}

It is going to use the self-assessment instrument, developed by Vance et al. (2007) and refined by Groves \& Valence (2014), which measures an individual's overall linear and nonlinear thinking style profile and includes the following thinking constituents: creative, linear, values-centred, imaginative, intuitive, flexible, imaginative and emotional one.

\section{Divergent and convergent thinking, motivation and emotion}

It is proposed to use the measure EDICOS (the Emotion/Motivation-related Divergent and Convergent thinking styles Scale) concerning individual differences in emotional and motivational reactions to divergent and convergent thinking.

\section{Individual learning and performance goal orientation}

Button et al.'s (1996) measure is proposed (reliability: Learning Orientation 0.78, Performance Orientation 0,82). The exemplary items measuring learning and performance goal orientation are: 'I prefer to work on tasks that force me to learn new things' and 'I like to be fairly confident that I can successfully perform a task before I attempt it' respectively.

Proactive personality

Bateman \& Crant's (1993) measure is proposed - Cronbach's alpha is .79. The exemplary item is: 'If I believe in an idea, no obstacle will prevent me from making it happen'.

\section{Creative Personality}

It is proposed to use Gough's (1979) Creative Personality Scale (CPS) that is well-regarded assessment method using self-reports.

\section{Creativity at the individual level}

There are around 260 creativity measurement instruments (see Cropley 2000). It is proposed to use Horng, Tsai \& Chung's (2016) measure. The exemplary item is: 'I will search out new technologies, processes, techniques, and/or product ideas when I am learning.'

Creativity at the team level

The Jiang \& Zhang's (2014) three-item scale is proposed to be adopted to measure team creative action - the respective coefficient alpha is .719. The items are: 'Team members can effectively co-operate and interact with each other', 'Team members can exchange creative 
knowledge without obstacle', and 'Team leaders can arouse the members' creative enthusiasm through various means'.

Team tasks routinization

Becker \& Knudsen's (2001) measure with the Cronbach's alpha 0,74 would be adopted. It evaluates (a) frequency of use of task groups in preparing strategic decisions, (b) frequency of use of task groups in development schemes, (c) frequency of use of fixed goals for controlling costs, (d) frequency of use of fixed goals for production costs, and (e) frequency of comparative analysis of production cost variations with regard to goals.

Learning and performance team members'goal orientation

Jha \& Bhattacharyya's (2013) scale is proposed (with reliability Learning Orientation 0.65, Performance Orientation 0,56). The exemplary items measuring learning and performance goal orientation are: 'I get intrinsically motivated to constantly expand my knowledge' and 'I generally perform and undertake those tasks for which I get rewarded soon' respectively.

\section{Goal difficulty}

The measure adopted from LePine (2005) - reliable from both an internal consistency (mean item alpha across members 0.89 ) and interrater perspective (ICC2 0.62). The items are: 'How difficult was your assigned goal?' (1 - very easy; 5 - very difficult) and 'How challenging was your assigned goal?' (1 - very unchallenging, 5 - very challenging).

\section{Innovation-oriented leadership}

Wang \& Ahmed's (2004) scale is suggested. The items are: 'We encourage people to think and behave in original and novel ways', 'We get a lot of support from managers if we want to try new ways of doing things'. The Cronbach $\alpha$ was .87 .

\section{Transaction Memory Systems}

It is suggested incorporating Lewis's (2003) scale including 15 items over three dimensions: specialization, credibility, and coordination. The Cronbach $\alpha$ is .76.

\section{Creative self-efficacy}

It is proposed to use Tierney \& Farmer's (2002) three item scale. The exemplary item is: 'I am confident in my ability to solve problems creatively.' The Cronbach $\alpha$ is .89 . It will be necessary to aggregate individual responses into team-level constructs.

\section{Creativity at the organizational level}

It is proposed to incorporate either KEYS assessing the climate for creativity (Amabile, 1996) or Ekvall's (1988) Creative Climate Questionnaire-t (CCQ).

Creative performance at the individual level

Hocevar's (1979) and Kirschenbaum's (1989) Creative Behavior Inventory (CBI) as well as a 3-item scale developed by Oldham \& Cummings (1996) - the exemplary item is 'How 
original and practical is this person's work?'

Creative performance at the team level

A panel of judges is proposed to be conducted or the Jiang and Zhang's (2014) three-item scale to assess the team creative outcome. The scale includes the following items: 'The team can realize creative outcome fluently', 'The team can realize creative outcome with high quality', and 'The team can realize creative outcome with great economic and social value'. The coefficient alfa is: , 755 .

\section{Creative performance at the organizational level}

It is proposed to measure product creativity using a Creative Solution Diagnosis Scale (CSDS) developed by Cropley \& Cropley (2005) and revised by Cropley, Kaufman \& Kropley (2011) including the following elements to be assessed: Relevance \& Effectiveness, Problematization, Propulsion, Elegance, and Genesis.

\section{Innovative performance at the individual level}

Innovative performance comprehended as innovative behaviour is proposed to be measured with Scott \& Bruce's (1994) five-item scale (a self-report measure). An exemplary item is: 'At work, I always promote and champion ideas to others.' The Cronbach's $\alpha$ is .87 . The measure of a number of novel ideas implemented in a given time might be also considered.

Innovative performance at the team level

It is proposed to use a reliable and well-validated (Cronbach's $\alpha$ for the scale was 0.82) four-item innovative performance scale developed by Welbourne, Johnson \& Erez (1998). The exemplary items are 'Working to implement new ideas', 'Creating better processes and routines'.

\section{Innovative performance at the organizational level}

To evaluate organizational innovative performance it is proposed to use the idea of Therin (2003) with regard to product Innovation, adoption of new product technologies, adoption of new process technologies, and transforming $R \& D$ results into products.

\section{Opening and closing leadership behaviour}

The scale of Rosin et al. (2011) is suggested. The item for opening leadership behaviour is 'Allows different ways of accomplishing a task'. Cronbach's $\alpha$ for the scale was 0.89 . The item for closing leadership behaviour is 'Monitors and controls goal attainment'. Cronbach's $\alpha$ for the scale was 0.85 . Individual employee ratings from each firm were aggregated to the team level by computing the means.

\section{Exploration and exploitation behaviour}

It is proposed to incorporate Mom, van den Bosch \& Volberda's (2007) measure. The exemplary item for exploration and exploitation behaviour is: 'Searching for new possibilities with respect to my work' and 'Activities in which I have accumulated a lot of experience', 
respectively. Cronbach's alpha for this scale was .83 .

\section{Control variables}

It is recommended to use three control variables: (1) team success perception - a single item adapted from a study by van Dyck et al. (2005): 'How successful is your team in comparison to other teams in the same line of industry and of (about) the same size?', (2) organization size, and (3) high and low velocity industries.

\section{Conclusion}

The paper introduces, develops, and illustrates a conceptual framework with regard to the relationships between creativity, ambidextrous leadership and innovative performance incorporating a multi-level homologous perspective drawing on current developments within those realms. Hence, the main contribution refers to propose a framework for exploring creativity from the perspective of ambidextrous leadership for innovation and innovative performance within the multilevel research methodology, namely homologous multilevel models (Klein, Kozlowski, 2000). Nonetheless, the contribution requires further empirical investigation in the future.

Moreover, it is proposed to start thinking about the creativity construct in terms of embedding it in the context and to analysing the whole process of creating a particular creative and innovative output using qualitative methodology (e.g. ethnography) as well as longitudinal data collection methods that might help explore temporal and emergent changes in creative behaviour (temporal flexibility) and the process of integrating tensions (opening and closing behaviour, exploitation and exploration behaviour). Then, that qualitative approach might be assigned and compared to the quantitative measures aforementioned (compare Piórkowska, $2016 \mathrm{~b}$ for the review of methodology used in research on creativity).

\section{Acknowledgement}

The publication is realized in the scope of the project that has been financed by the National Scientific Centre in Poland on the basis of the decision no. DEC-2012/05/D/HS4/01317.

\section{References}

Amabile, T.M. (1996). Creativity in context. Boulder, CO: West view.

Amabile, T.M. (1997). Motivating creativity in organizations: on doing what you love and loving what you do. California Management Review, 40(1), 39-58. https://doi.org/10.2307/41165921

Amabile, T.M., Conti, R., Coon, H., Lazenby J., \& Herron, M. (1996). Assessing the Work Environment for Creativity. The Academy of Management Journal, 39(5), 1154-1184. https://doi.org/10.2307/256995

Anderson, N., Potočnik, K., \& Zhou J (2014). Innovation and Creativity in Organizations: A State-of-the-Science Review, Prospective Commentary, and Guiding Framework. Journal of Management, 40, 1247-1333. https://doi.org/10.1177/0149206314527128

Armstrong, A., \& Page, N. (2015). Creativity and constraint: leadership and management in 
the UK creative industries. London: Creative Skillset.

Bateman, T.S., \& Crant, J.M. (1993). The proactive component of organizational behavior. Journal of Organizational Behavior, 14, 103-118. https://doi.org/10.1002/job.4030140202

Batey, M. (2012). The measurement of creativity: From definitional consensus to the introduction of a new heuristic framework. Creativity Research Journal, 24(1), 55-65. https://doi.org/10.1080/10400419.2012.649181

Batey, M., Chamorro-Premuzic, T., \& Furnham, A. (2009). Intelligence and personality as predictors of divergent thinking: the role of general, fluid and crystallised intelligence. Thinking Skills and Creativity, 4(1), 60-66. https://doi.org/10.1016/j.tsc.2009.01.002

Batey, M., Furnham, A., \& Safiullina, X. (2010), Intelligence, general knowledge and personality as predictors of creativity. Learning and Individual Differences, 20, 532-535. https://doi.org/10.1016/j.lindif.2010.04.008

Bilton,C., \& Leary, R. (2002).What can managers do for creativity? Brokering creativity in the creative industries. International Journal of Cultural Policy, 8, 49-64. https://doi.org/10.1080/10286630290032431

Bledow, R., Frese, M., Anderson, N., Erez, M., \& Farr, J. (2009). A dialectic perspective on innovation: Conflicting demands, multiple pathways, and ambidexterity. Industrial and Organizational Psychology, 2, 305-337. https://doi.org/10.1111/j.1754-9434.2009.01154.x

Bledow, R., Rosing, K., \& Frese, M. (2013). A dynamic perspective on affect and creativity. Academy of Management Journal, 56, 432-450. https://doi.org/10.5465/amj.2010.0894

Bono, J.E., \& Judge, T.A. (2003). Self-concordance at work: Toward understanding the motivational effects of transformational leaders. Academy of Management Journal, 46, 554-571. https://doi.org/10.2307/30040649

Bouchard, V., \& Bos, C. (2006). Dispositifs intrapreneuriaux et créativité organisationnelle: une conception tronquée? Revue Française de Gestion, 32 (161), 93-114. https://doi.org/10.3166/rfg.161.95-109

Burt, R.S. (2004). Structural holes and good ideas. American Journal of Sociology, 110, 349-399. https://doi.org/10.1086/421787

Button, S.B., Mathieu, J.E., \& Zajac, D.M. (1996). Goal orientation in organizational research: A conceptual and empirical foundation. Organizational Behavior and Human Decision Processes, 67(1), 26-48. https://doi.org/10.1006/obhd.1996.0063

Carnevale, A. P., Gainer, L. J., \& Meltzer, A. (1990). Workplace basics: The essential skills employers want. San Francisco: Jossey-Bass.

Cropley, A. (2000). Defining and measuring creativity: Are creativity tests worth using? Roeper Review, 2, 72-100. https://doi.org/10.1080/02783190009554069

Cropley, D.H., \& Cropley, A.J. (2010). Functional Creativity: Products and the generation of effective novelty. In J. C. Kaufman, \& R. J. Sternberg (Eds.), Cambridge Handbook of Creativity (pp. 301-320). New York: Cambridge University Press. https://doi.org/10.1017/CBO9780511763205.019

Cropley, D.H., \& Cropley, A.J. (2012). A psychological taxonomy of organizational innovation: Resolving the paradoxes. Creativity Research Journal, 24, 29-40. 
https://doi.org/10.1080/10400419.2012.649234

Cropley, D.H., Kaufman, J.C., \& Cropley, A.J. (2011). Measuring Creativity for Innovation Management, Journal of Technology Management, \& Innovation, 6(3), 13-29. https://doi.org/10.4067/S0718-27242011000300002

Csikszentmihalyi, M. (1988). Society, culture, and person: A systems view of creativity. In R.J. Sternberg (Ed.), The nature of creativity (pp. 325-339), New York: Cambridge University Press.

Csikszentmihalyi, M. 2006. La créativité - Psychologie de la découverte et de l'invention. Paris: Laffont.

Davis, M.A. (2009). Understanding the relationship between mood and creativity: A meta analysis. Organizational Behavior and Human Decision Processes, 108, 25-38. https://doi.org/10.1016/j.obhdp.2008.04.001

De Dreu, C.K., Baas, M.,, \& Nijstad, B.A. (2008). Hedonic tone and activation level in the mood-creativity link: Toward a dual pathway to creativity model. Journal of Personality and and Social Psychology, 94, 739-756. https://doi.org/10.1037/0022-3514.94.5.739

DeFillippi, R., Grabher, G., \& Jones, C. (2007). Introduction to Paradoxes of Creativity: Managerial and Organizational Challenges in the Cultural Economy. Journal of Organizational Behavior, 28(5), Paradoxes of Creativity: Managerial and Organizational Challenges in the Cultural Economy, 511-521.). https://doi.org/10.1002/job.466

Dewett, T. (2004). Creativity and strategic management. Journal of Managerial Psychology, 19(2), 156-169. https://doi.org/10.1108/02683940410526118

Dyduch, W., \& Bratnicki, M. (2010). Exploring, exploiting and effective? The dialectics of entrepreneurial learning and performance in post-accession economy organizations (interactive paper). Frontiers of Entrepreneurship Research, 30 (12), 1-19.

Edwards-Schachter, M., García-Granero, A., Sánchez-Barrioluengo, M., Quesada, H., \& Amara, N. (2015). Disentangling competences: Interrelationships on creativity, innovation and entrepreneurship. Thinking Skills and Creativity, 16, 27-39. https://doi.org/10.1016/j.tsc.2014.11.006

Elliott, E., \& Dweck, C. (1988). Goals: an approach to motivation and achievement. Journal of Personality and Social Psychology, 54(1), 5-12. https://doi.org/10.1037/0022-3514.54.1.5

Eysenck, H. (2003). Creativity, personality, and the convergent-divergent continuum. In: Critical creative processes, M.A Runco (Ed.), pp 95-114, NJ, Cresskill: Hampton Press.

Fan, H-L., Chang, P.-F., Albanese, D., Wu, J.-J., Yu, M.-J., \& Chuang, H.-J. (2016). Multilevel influences of transactive memory systems on individual innovative behavior and team innovation, Thinking Skills and Creativity, 19, 49-59.

Feldman, M.S. (2000). Organizational routines as a source of continuous change. Organization Science, 11(6), 611-629. https://doi.org/10.1287/orsc.11.6.611.12529

Fischer, S., Oget, D., \& Cavallucci, D. (2015). The evaluation of creativity from the perspective of subject matter and training in higher education: Issues, constraints and limitations. Thinking Skills and Creativity, 19, 123-135. https://doi.org/10.1016/j.tsc.2015.10.002 
Florida, R. (2002). The Rise of the Creative Class, New York: Basic Books.

Furnham, A., \& Bachtiar, V. (2008). Personality and intelligence as predictors of creativity, $\begin{array}{lll}\text { Personality and Individual } & \text { 613-617. }\end{array}$ https://doi.org/10.1016/j.paid.2008.06.023

George, J.M. (2007). Creativity in Organizations, Academy of Management Annals, 1, 439-477. https://doi.org/10.1080/078559814

George, J.M., \& Zhou, J. (2001). When openness to experience and conscientiousness are related to creative behavior: An interactional approach. Journal of Applied Psychology, 86, 513-524. https://doi.org/10.1037/0021-9010.86.3.513

Gibson, C.B., \& Birkinshaw, J. (2004). The antecedents, consequences, and mediating role of organizational ambidexterity. Academy of Management Journal, 47, 209-226. https://doi.org/10.2307/20159573

Gilson, L.L.,, \& Shalley, Ch.E. (2004). A Little Creativity Goes a Long Way: An Examination of Teams' Engagement in Creative Processes. Journal of Management, 30(4), 453-470. https://doi.org/10.2307/20159573

Glaveanu, V.P. (2015). Creativity as a Sociocultural Act. The Journal of Creative Behavior, 49(3), 165-180. https://doi.org/10.1002/jocb.94

Gong, Y., Huang, J.-C.,, \& Farh, J.-L. (2009). Employee learning orientation, transformational leadership, and employee creativity: The mediating role of employee creative self-efficacy. Academy of Management Journal, 52, 765-778. https://doi.org/10.1108/dlo.2010.08124bad.003

Groves, K.S., \& Vance, Ch.M. (2014). Linear and Nonlinear Thinking: A Multidimensional Model and Measure. The Journal of Creative Behavior, 49(2), 111-136. https://doi.org/10.1002/jocb.60

Gough, H.G. (1979). A creative personality scale for the Adjective Check List. Journal of $\begin{array}{lllll}\text { Personality and Social Pschology, } & \text { 37, } & \text { 1398-1405. }\end{array}$ https://doi.org/10.1037/0022-3514.37.8.1398

Guilford, J.P. (1950). Creativity. American Psychologist, 5, 444-454. https://doi.org/10.1037/h0063487

Gupta, A.K., Smith, K.G., \& Shalley, C.E. (2006). The interplay between exploration and exploitation. Academy of Management Journal, 49, 693-706. https://doi.org/10.5465/AMJ.2006.22083026

Haner, U.-E. (2005). Spaces for creativity and innovation in two established organizations. Creativity and Innovation Management, 14, 288-298. https://doi.org/10.1111/j.1476-8691.2005.00347.x

Hennessey, B.A., \& Amabile, T.M. (2010). Creativity. Annual Review of Psychology, 61, 569-598. https://doi.org/10.1146/annurev.psych.093008.100416

Higgins, E.T. (1997). Beyond Pleasure and Pain. American Psychologist, 52(12), 1280-1300. https://doi.org/10.1037/0003-066X.52.12.1280

Higgins, E.T. (2014). Promotion and prevention: How “0” can create dual motivational forces, In: J. Sherman, B. Gawronski, and Y. Trope (Eds.), Dual-process theories of the social 
mind (pp. 423-436), , New York: Guilford Press.

Hirst, G., Van Knippenberg, D., Chen, C.H., \& Sacramento, C.A. (2011). How does bureaucracy impact individual creativity? A cross-level investigation of team contextual influences on goal orientation-creativity relationships. Academy of Management Journal, 54, 624-641. https://doi.org/10.5465/AMJ.2011.61968124

Hocevar, D. (1979). The Development of the Creative Behavior Inventory (CBI). Paper presented at the annual meeting of the Rocky Mountain Psychological Association. (ERIC Document Reproduction Service No. ED 170 350).

Hui, A.N.N. (2015). Challenging views and creative insights from a social cultural perspective. Journal of Creative Behavior, 49, 231-237. https://doi.org/10.1002/jocb.129

Inkinen, S., \& Kaivo-oja, J. (2009). Understanding innovation dynamics Aspects of Creative Processes, Foresight Strategies, Innovation Media, and Innovation Ecosystems. FFRC E-book, 9/2009.

Jha, S., \& Bhattacharyya, S.S. (2013). Learning orientation and performance orientation: Scale development and its relationship with performance. Global Business Review, 14(1), 43-54. https://doi.org/10.1177/0972150912466443

Jiang, H., \& Zhang, Q.-P. (2014). Development and Validation of Team Creativity Measures: A Complex Systems Perspective. Creativity and innovation management, 23(3), 264-275. https://doi.org/10.1111/caim.12078

Jung, D.I., Chow, C., \& Wu, A. (2003). The role of transformational leadership in enhancing organizational innovation: Hypotheses and some preliminary findings. The Leadership Quarterly, 14, 525-544. https://doi.org/10.1016/S1048-9843(03)00050-X

Kalis, E., Roke, L., \& Krumina, I. (2014). Investigation of Psychometric Properties of the Test for Creative Thinking-Drawing Production: Evidence from Study in Latvia. The Journal of Creative Behavior, 50(1), 47-63. https://doi.org/10.1002/jocb.68

Kaufman, J.C. (2015). Creativity is life: A commentary on the special issue. Journal of Creative Behavior, 49, 225-230. https://doi.org/10.1002/jocb.128

Kim, T-Y, Hon, A.H.Y., \& Crant, J.M. (2009). Proactive Personality, Employee Creativity, and Newcomer Outcomes: A Longitudinal Study. Journal of Business and Psychology, 24, 93-103. https://doi.org/10.1007/s10869-009-9094-4

Kim, T-Y, Hon, A.H.Y., \& Lee, D-R. (2010). Proactive Personality and Employee Creativity: The Effects of Job Creativity Requirement and Supervisor Support for Creativity. Creativity Research Journal, 22(1), 37-45. https://doi.org/10.1080/10400410903579536

Kind, P.M., \& Kind, V. (2007). Creativity in science education: perspectives and challenges for developing school science. Studies in Science Education, 43(1), 1-37. https://doi.org/10.1080/03057260708560225

Kirschenbaum, R.J. (1989). Understanding the creative activity of students: Including an instruction manual for the creative behavior inventory. St. Louis, MO: Creative Learning Press.

Kirton, M.J. (1976). Adaptors and innovators: A description and measure. Journal of Applied Psychology, 61, 622-629. https://doi.org/10.1037/0021-9010.61.5.622 
Kirton, M.J. (1994). Adaptors and innovators: Styles of creativity and problem solving (2nd ed.). New York: Routledge.

Klein K.J., \& Kozlowski, S.W.J. (2000). From Micro to Meso: Critical Steps in Conceptualizing and Conducting Multilevel Research, Organizational Research Methods, 3(3), 211-236. https://doi.org/10.1177/109442810033001

Klein, H.J., Wesson, M.J., Hollenbeck, J.R., Wright, P.M., \& DeShon, R. P. (2001). The assessment of goal commitment: A measurement model meta-analysis, Organizational Behavior and Human Decision Processes, 85, 32-55. https://doi.org/10.1006/obhd.2000.2931

Lewis, K. (2003). Measuring transactive memory systems in the field: scale development and validation. Journal of Applied Psychology 88(4), 587-604. https://doi.org/10.1037/0021-9010.88.4.587

Lewis, K., \& Herndon, B. (2011). Transactive memory systems: current issues and future $\begin{array}{llll}\text { research directions. } & \text { Organization } & \text { Science, } & \text { 22(5), }\end{array}$ https://doi.org/10.1287/orsc.1110.0647

Liang, Ch., Chang Ch.-Ch.,, \& Hsu, Y. (2014). Differential Effects of Personality Traits and Environmental Predictors on Reproductive and Creative Imagination. The Journal of Creative Behavior, 48 (4), 237-253. https://doi.org/10.1002/jocb.50

Long, H. (2014). An Empirical Review of Research Methodologies and Methods in Creativity Studies (2003-2012). Creativity Research Journal, 26(4), 427-438. https://doi.org/10.1080/10400419.2014.961781

Lubart, T.I. (2001). Models of the Creative Process: Past, Present and Future. Creativity Research Journal, 13(3-4), 295-308. https://doi.org/10.1207/S15326934CRJ1334_07

March, J.G. (1991). Exploration and exploitation in organizational learning. Organization Science, 2, 71-87. https://doi.org/10.1287/orsc.2.1.71

Massaro, M., Bardy, R., \& Pitts. M. (2012). Supporting creativity through knowledge integration during the creative processes. A management control system perspective. The Electronic Journal of Knowledge Management, 10(3), 258-267.

Mecca, J.T., \& Mumford, M.D. (2014). Imitation and Creativity: Beneficial Effects of Propulsion Strategies and Specificity. The Journal of Creative Behavior, 48 (3), 209-236. https://doi.org/10.1002/jocb.49

Mom, T.J.M., van den Bosch, F.A.J., \& Volberda H.W. (2007). Investigating managers' exploration and exploitation activities: The influence of top-down, bottom-up, and horizontal knowledge inflows. Journal of Management Studies, 44, 910-931. https://doi.org/10.1111/j.1467-6486.2007.00697.x

Mumford, M., \&Gustafson, S.B. (1988). Creativity Syndrome: Integration, Application, and Innovation. Psychological Bulletin, 103, 27-43.

Nesta. (2014). Mentoring in the Creative Sector: Industry insights. https://www.nesta.org.uk/sites/default/files/mentoring_in_the_creative_sector.pdf.

Ogilvie, D.T. (1998). Creative action as a dynamic strategy: Using imagination to improve strategic solutions in unstable environments. Journal of Business Research, 41, 49-56. https://doi.org/10.1016/S0148-2963(97)00011-8 
Oldham, G.R., \& Cummings, A. (1996). Employee creativity: personal and contextual factors at work. Academy of Management Journal, 9(3), 607-634. https://doi.org/10.2307/256657

Park, N.K., Chun, M.Y., \& Lee, J. (2016). Revisiting Individual Creativity Assessment: Triangulation in Subjective and Objective Assessment Methods. Creativity Research Journal, 28(1), 1-10. https://doi.org/10.1080/10400419.2016.1125259

Patterson, M.G., West, M.A., Shackleton, V.J., Dawson, J.F., Lawthom, R., Maitlis, S., Robinson, D.L.,, \& Wallace, A.M. (2005). Validating the organizational climate measure: Links to managerial practices, productivity and innovation. Journal of Organizational Behavior, 26, 379-408. https://doi.org/10.1002/job.312

Perry-Smith, J.E. (2006). Social yet creative: The role of social relationships in facilitating individual creativity. Academy of Management Journal, 49, 85-101. https://doi.org/10.5465/AMJ.2006.20785503

Piórkowska, K. (2016a). Creativity, Ambidextrous Leadership and Innovative Performance: A Multi-Level Conceptual Framework, Proceedings of The 27th International Business Information Management Association Conference: Innovation Management and Education Excellence Vision 2020: From Regional Development Sustainability to Global Economic Growth, Soliman K.S. (ed.), International Business Information Management Association (IBIMA), 3316-3322.

Piórkowska, K. (2016b). Ontological, epistemological and methodological taxonomy of creativity phenomenon research - call for path forward. Journal of Economics and Management, 25(3), 97-108. https://doi.org/10.22367/jem.2016.25.07

Plucker, J.A., \& Beghetto, R.A. (2004). Why creativity is domain general, why it looks domain specific, and why the distinction does not matter. In R.J. Sternberg, E.L. Grigorenko and J.L. Singer (Eds.), Creativity: From potential to realization (pp. 153-198). Washington: APA. https://doi.org/10.1037/10692-009

Ren, Y.Q., \& Argote, L. (2011). Transactive memory systems 1985-2010: an integrative framework of key dimensions, antecedents, and consequences. Academy of Management Annals, 5, 189-229. https://doi.org/10.1080/19416520.2011.590300

Rosing, K., Frese, M., \& Bausch, A. (2011). Explaining the heterogeneity of the leadershipinnovation relationship: ambidextrous leadership. Leadership Quarterly, 22(5), 956-974. https://doi.org/10.1016/j.leaqua.2011.07.014

Roskes, M., De Dreu, C.K., \& Nijstad, B.A. (2012). Necessity Is the Mother of Invention: Avoidance Motivation Stimulates Creativity Through Cognitive Effort. Journal of Personality and Social Psychology, 103(2), 242-256. https://doi.org/10.1037/a0028442

Runco, M.A. (2004). Creativity. Annual Review of Psychology, 55, 657-687. https://doi.org/10.1146/annurev.psych.55.090902.141502

Runco, M.A. (2007). Creativity. Theories and themes: Research, development, and practice Burlington, MA: Elsevier Academic Press.

Runco, M.A. (2014). Creativity: theories and themes. Research, development, and practice. San Diego, CA: Elsevier.

Runco, M.A., \& Acar, S. (2012). Divergent thinking as an indicator of creative potential. Creativity Research Journal, 24, 66-75. https://doi.org/10.1080/10400419.2012.652929 
Runco, M.A., \& Jaeger, G.J. (2012). The standard definition of creativity. Creativity Research Journal, 24, 92-96. https://doi.org/10.1080/10400419.2012.650092

Russell, J.A., \& Carroll, J.M. (1999). On the bipolarity of positive and negative affect. Psychological Bulletin, 125, 3-30. https://doi.org/10.1037/0033-2909.125.1.3

Scott, S.G., \& Bruce, R.A. (1994). Determinants of innovative behavior of employees: evidence from Spanish firms. Academy of Management Journal, 37(3), 580-607. https://doi.org/10.2307/256701

Seibert, S.E., Crant, J.M., \& Kraimer, M.L. (1999). Proactive personality and career success. Journal of Applied Psychology, 84, 416-427. https://doi.org/10.1037/0021-9010.84.3.416

Seibert, S.E., Kraimer, M.L., \& Crant, J.M. (2001). What do proactive people do? A longitudinal model linking proactive personality and career success. Personnel Psychology, 54, 845-874. https://doi.org/10.1111/j.1744-6570.2001.tb00234.x

Shalley, Ch.E., Gilson, L.L., \& Terry, C. (2000). Matching Creativity Requirements and the Work Environment: Effects on Satisfaction and Intentions to Leave. The Academy of Management Journal, 43(2), 215-223. https://doi.org/10.2307/1556378

Shalley, Ch.E., Zhou, J., \& Oldham, G.R. (2004). The Effects of Personal and Contextual Characteristics on Creativity: Where Should We Go from Here? Journal of Management, 30 (6), 933-958.

Shin, S.J., \& Zhou, J. (2003). Transformational leadership, conservation, and creativity: Evidence from Korea. Academy of Management Journal, 46, 703-714. https://doi.org/10.2307/30040662

Simonton, D.K. (2008). Creativity and genius. In L.A. Pervin, R.W. Robins, and O.P. John (Eds.), Handbook of Personality: Theory and Research (pp. 679-701), New York: Guilford Press.

Soroa G., Balluerka, N., Hommel, B., \& Aritzeta, A. (2015). Assessing interactions between cognition, emotion, and motivation in creativity: The construction and validation of EDICOS. Thinking Skills and Creativity, 17, 45-58. https://doi.org/10.1016/j.tsc.2015.05.002

Sternberg, R.J. (1999). A propulsion model of creative contributions. Review of General Psychology, 3, 83-100. https://doi.org/10.1037/1089-2680.3.2.83

Sternberg, R.J. (2006). The Nature of Creativity. Creativity Research Journal, 18(1), 87-98. https://doi.org/10.1207/s15326934crj1801_10

Sternberg, R.J., \& Ben-Zeev, T. (2001). Complex Cognition: The Psychology of Human Thought, New York: Oxford University Press.

Sternberg, R.J., \& Kaufman, S.B. (2012). Trends in intelligence research. Intelligence, 40, 235-236. https://doi.org/10.1016/j.intell.2012.01.007

Sternberg, R.J., Kaufman, J.C., \& Pretz, J.E. (2001). The propulsion model of creative contributions applied to the arts and letters. Journal of Creative Behavior, 35(2), 75-101. https://doi.org/10.1002/j.2162-6057.2001.tb01223.x

Sternberg, R.J., Kaufman, J.C., \& Pretz, J.E. (2002). The creativity conundrum: A propulsion model of kinds of creative contributions. New York: Psychology Press. 
Sternberg, R.J., \& Lubart, T.I. (1991). An investment theory of creativity and its development. Human Development, 34(1), 1-31. https://doi.org/10.1159/000277029

Sternberg, R.J., \& Lubart, T.I. (1995). Defying the crowd. New York: Free Press.

Taing, M.U., Smith, T., Singla, N., Johnson R.E., \& Chang Chu-H. (2013). The relationship between learning goal orientation, goal setting, and performance: A longitudinal study. Journal of Applied Social Psychology, 43(8), 1668-1675. https://doi.org/10.1111/jasp.12119

Tan, A.G., \& Wong, M.E. (2015). Commentary: Toward Convergence in Creativity Inquiry. The Journal of Creative Behavior, 49(3), 238-244. https://doi.org/10.1002/jocb.130

Therin, F. (2003). Learning Organization and Innovation Performance in High-Tech Small Firms. Working paper serie RMT (WPS 03-06).

Tierney, P., \& Farmer, S.M. (2002). Creative self-efficacy: its potential antecedents and relationship to creative performance. Academy of Management Journal, 45(6), 1137-1148. https://doi.org/10.2307/3069429

Torrance, E.P. (1962). Guiding creative talent. NJ, Englewood Cliffs: Prentice Hall. https://doi.org/10.1037/13134-000

Torrance, E.P. (1974). Torrance tests of creative thinking. MA, Lexington: Personnel Press.

Torrance, E.P. (2007). Torrance tests of creative thinking. Manual. Bensenville, IL: Scholastic Testing Service.

Turkson, J.K., \& Appiah, K.O (2009). Managerial Creativity and Innovation: A Panacea for Organizational Change and Development. Global Business and Economics Anthology, II, 117-126.

Urban, K.K. (2004). Assessing creativity: The test for creative thinking - Drawing production (TCT-DP). The concept, application, evaluation, and international studies. Psychology Science, 46, 387-397.

Urban, K.K., \& Jellen, H.G. (2010). Test for creative thinking - Drawing production (TCT-DP). Manual. Frankfurt: Pearson.

Vandewalle, D. (2001). Goal orientation: Why wanting to look successful doesn't always lead to success. Organizational Dynamics, $30(2), \quad 162-171$. https://doi.org/10.1016/S0090-2616(01)00050-X

VandeWalle, D., Brown, S., Cron, W.,, \& Slocum, J. (1999). The influence of goal orientation and self-regulation tactics on sales performance: A longitudinal study. Journal of Applied Psychology, 84(2), 249-259. https://doi.org/10.1037/0021-9010.84.2.249

VandeWalle, D., Cron, W., \& Slocum, J. (2001). The role of goal orientation following performance feedback. Journal of Applied Psychology, 86(4), 629-640. https://doi.org/10.1037/0021-9010.86.4.629

Van de Ven, A.H., Polley, D.E., Garud, R, \& Venkataraman, S. (1999). The innovation journey. New York: Oxford University Press.

van Dyck, C., Frese, M., Baer, M., \& Sonnentag, S. (2005). Organizational error management culture and its impact on performance: a two-study replication. Journal of Applied Psychology, 90 (6), 1228-1240. https://doi.org/10.1037/0021-9010.90.6.1228 
Wallas, G. (1926). The Art of Thought, New York: Harcourt, Brace.

Wang, C.L., \& Ahmed P.K. (2004). The development and validation of the organisational innovativeness construct using confirmatory factor analysis. European Journal of Innovation Management, 7(4), 303-313. https://doi.org/10.1108/14601060410565056

Wang, P., \& Zhu, W. (2011). Mediating role of creative identity in the influence of transformational leadership on creativity: Is there a multilevel effect? Journal of Leadership and Organizational Studies, 18, 25-39. https://doi.org/10.1177/1548051810368549

Wehner, L., Csikszentmihalyi, M., \& Magyari-Beck, I. (1991). Current approaches used in studying creativity: An exploratory investigation. Creativity Research Journal, 4, 261-271. https://doi.org/10.1080/10400419109534398

Welbourne, T.M., Johnson, D.E., \& Erez, A. (1998). The role-based performance scale: Validity analysis of a theory-based measure. Academy of Management Journal, 41, 540-555. https://doi.org/10.2307/256941

Werner, Ch.H., Tang, M., Kruse, J., Kaufman, J.C., \& Spörrle, M. (2014). The Chinese Version of the Revised Creativity Domain Questionnaire (CDQ-R): First Evidence for its Factorial Validity and Systematic Association with the Big Five. The Journal of Creative Behavior, 48(4), 254-275. https://doi.org/10.1002/jocb.51

West, M.A. (2002). Sparkling fountains or stagnant ponds: An integrative model of creativity and innovation implementation in work groups. Applied Psychology: An International Review, 51, 355-424. https://doi.org/10.1111/1464-0597.00951

West, M.A., \& Farr, J.L. (1990). Innovation and Creativity at Work: Psychological and Organizational Strategies. Chichester: Wiley.

Williams, F., \& Foti, R.J. (2011). Formally developing creative leadership as a driver of organizational innovation. Advances in Developing Human Resources, 13, 279-296. https://doi.org/10.1177/1523422311424702

Woodman, R.W., Sawyer, J.E., \& Griffin, R.W. (1993). Toward a theory of organizational creativity, Academy of Management Review, 18, 293-321. https://doi.org/10.5465/AMR.1993.3997517

Wong, C.-K.S., \& Pang, W.-L.L. (2003). Barriers to creativity in the hotel industry perspectives of managers and supervisors. International Journal of Contemporary Hospitality Management, 15(1), 29-37. https://doi.org/10.1108/09596110310458963

Zacher, H., \& Johnson, E. (2014). Leadership and creativity in higher education. Studies in Higher Education, advance online publication. https://doi.org/10.1080/03075079.2014.881340

Zacher, H., Robinson, A.J., \& Rosing, K. (2016). Ambidextrous Leadership and Employees' Self-Reported Innovative Performance: The Role of Exploration and Exploitation Behaviors. The Journal of Creative Behavior, 50(1), 24-46. https://doi.org/10.1002/jocb.66

Zacher, H., \& Rosing, K. (2015). Ambidextrous leadership and team innovation. Leadership, \& Organization Development Journal, 36(1), 54-68. https://doi.org/10.1108/LODJ-11-2012-0141

Zhang, L., \& Sternberg, R.J. (Eds.). (2009). Perspectives on the nature of intellectual styles, 
New York: Springer.

Zhou, J. (2003). When the presence of creative coworkers is related to creativity: Role of supervisor close monitoring, developmental feedback, and creative personality. Journal of Applied Psychology, 88, 413-422. https://doi.org/10.1037/0021-9010.88.3.413

Zhou, J., \& George, J.M. (2001). When job dissatisfaction leads to creativity: encouraging the expression of voice. Academy of Management Journal, 44(4), 682-696. https://doi.org/10.2307/3069410

Zhou, J., \& Hoever, I.J. (2014). Research on workplace creativity: A review and redirection. Annual Review of Organizational Psychology and Organizational Behavior, 1, 11.1-11.27. https://doi.org/10.1146/annurev-orgpsych-031413-091226

\section{Copyright Disclaimer}

Copyright for this article is retained by the author(s), with first publication rights granted to the journal.

This is an open-access article distributed under the terms and conditions of the Creative Commons Attribution license (http://creativecommons.org/licenses/by/3.0/).

\footnotetext{
i The paper constitutes a developed and enhanced, to great extent, version of both the initial short paper presented at the 27th IBIMA conference 2016 (Piórkowska 2016a) and the paper concerning ontological, epistemological and methodological taxonomy of creativity (Piórkowska 2016b).
} 